Krut Yuri, Zemlyana Nataly, Savchenko Sergey. Diagnosis and prognostic value of markers of oncogenesis in patients with hyperplastic endometrial processes with uterine fibroids. Journal of Education, Health and Sport. 2020;10(1):136-141. eISSN 2391-8306. DOI http://dx.doi.org/10.12775/JEHS.2020.10.01.015

https://apcz.umk.pl/czasopisma/index.php/JEHS/article/view/JEHS.2020.10.01.015

https://zenodo.org/record/3632553

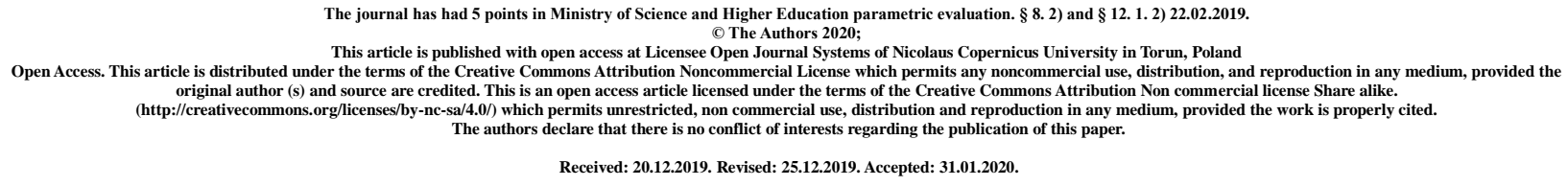

\title{
Diagnosis and prognostic value of markers of oncogenesis in patients with hyperplastic endometrial processes with uterine fibroids
}

\author{
Y. Ya. Krut, N. A. Zemlyana, S.E. Savchenko \\ Zaporizhzhya State Medical University, \\ Department of Obstetrics and gynecology
}

Yuri Yakovich Krut, MD, Professor, Head of the Department of Obstetrics and Gynecology ZSMU. Email: yuriy.krut@ukr.net. ORCID 0000-0002-0501-6752

Natalie Anatolyivna Zemlyana, Postgraduate student, Department of Obstetrics and Gynecology ZSMU. Email: natalyzemlyana@ gmail.com. ORCID 0000-0003-0678-1664

Sergey Evgenovich Savchenko, MD, Professor of Obstetrics, Gynecology and Reproduction department, NMAPO. savchenkoes@gmail.com. ORCID 0000-0003-3802-2187

Address for correspondence

Natalie Anatolyivna Zemlyana

Department of Obstetrics and Gynecology ZSMU

e-mail: natalyzemlyana@gmail.com

mailing address: Ukraine, city Zaporyzhya, Central Boulevard 1B, 16. Mail index 69005

\begin{abstract}
Introduction: The relevance of the study of the problem of endometrial hyperplastic processes (EHP) is due primarily to the high risk of malignancy of this pathology and its recurrent course. Despite numerous studies on EHP, some issues of pathogenesis, diagnosis and treatment of this pathology remain debatable.
\end{abstract}

Objective: To evaluate the levels of APRIL, survivin and phosphoPTEN in serum of women with various forms of EHP in combination with uterine fibroids and their prognostic value for recurrence. 
Materials and Methods: 105 women with endometrial hyperplastic processes and endometrial adenocarcinoma were examined during the study. The first group consisted of 34 women with simple endometrial hyperplasia without atypia (SEHWA), the second group included 47 patients with complex endometrial hyperplasia without atypia (CEHWA). The groups were divided into subgroups with or without uterine fibroids. The third group consisted of 26 women with endometrial adenocarcinoma.

Results: Level of APRIL was increased in the CEHWA group compared to the control group $(\mathrm{p}<0,05)$ and the SEHWA $(\mathrm{p}<0,05)$. Women with endometrial adenocarcinoma had significantly higher APRIL levels compared to controls and patients with both types of endometrial hyperplasia $(\mathrm{p}<0,05)$. Women with SEHWA had significantly higher level of survivin compared to controls $(\mathrm{p}<0,05)$. Patients with CEHWA and adenocarcinoma had serum levels of survivin higher than those in the control and SEHWA groups $(\mathrm{p}<0,05)$.

Conclusions: Adequate prognostic significance for the occurrence of relapses of EHP had the increasing of APRIL level greater than $43 \mathrm{pg} / \mathrm{ml}$ and survivin level greater than $70 \mathrm{pg} / \mathrm{ml}$. In patients with EHP in combination with uterine fibroids a significant risk factor for relapse was an increasing of APRIL level greater than $43 \mathrm{pg} / \mathrm{ml}$.

Key words: endometrial hyperplastic processes; uterine fibroids; biomarkers; survivin

\section{INTRODUCTION}

The relevance of the study of the problem of endometrial hyperplastic processes (EHP) is due primarily to the high risk of malignancy of this pathology and its recurrent course. The structure of EHP in gynecological pathology takes from 15 to $45 \%$ [1]. Thus the prevalence of different forms of endometrial hyperplasia and uterine fibroids among all gynecological disorders is about $75 \%$. The prevalence of uterine fibroids in women with endometrial hyperplasia ranges from 25 to $40 \%$ according to different researchers [2].

Proved that nearly 55\% of women endometrial cancer develops from the EHP [3]. This incidence of adenocarcinoma of the endometrium is growing in many countries, including in Ukraine [4]. Despite numerous studies on EHP, some issues of pathogenesis, diagnosis and treatment of this pathology remain debatable [3]. Much attention has recently been given for predictor search of relapse risk and EHP malignancy [5].

Proven role of comorbidities, including uterine fibroids, raising the risk of recurrence of endometrial hyperplasia [6]. It suggests common mechanisms of pathogenesis of these diseases. The combination of endometrial hyperplasia and uterine fibroids also contributes to the risk of malignancy. The high level of oncogenesis markers in this pathology was shown in recent studies [7]. This makes the actuality of search new non-invasive predictors of recurrence and malignancy with a combination of endometrial hyperplasia and uterine fibroids.

One of the mechanisms of malignant transformation and recurrence of endometrial hyperplasia is the increasing of mitotic activity and proliferation [9]. The most studied is considered a marker of proliferation Ki-67, which increases in endometrial hyperplasia compared with normal endometrium [9]. However, in other studies, the expression of Ki-67 decreased in endometrial hyperplasia compared with proliferating endometrium $[10,11]$. Therefore, continues the search for new markers, one of which is APRIL - ligand inducing proliferation. It is the type of membrane protein 2 ( $\mathrm{N}$-facing end of the cell), which is expressed by $\mathrm{T}$ cells, dendritic cells, monocytes, macrophages. Expression of APRIL growing in malignant tumors of various localization [12]. Thus ectopic expression of factors associated with increased of tumorogen in fibrosarcoma. According to Burley Y.D. was shown the increasing of this marker in the row of normal endometrium, simple hyperplasia, complex hyperplasia [13]. 
At the same time, the effect of APRIL on the proliferation induction at EHP at present is not defined. It is known that apoptosis inhibitors, one of which is survivin, play a role in the formation of endometrial hyperplasia and their recurrence [14].

Survivin is expressed predominantly in tumors and fetal tissues, but in terminally differentiated cells its expression is completely absent. It is proved that the expression of survivin increase in the row of proliferating endometrium, hyperplasia, endometrial adenocarcinoma (EA) [14].

Survivin rate increase by 2 times in endometrial hyperplasia with atypia compared with endometrial hyperplasia without atypia. This applies to both simple and complex forms of endometrial hyperplasia. The data of recent researches shows a decreasing level of apoptosis in atypical endometrial hyperplasia [14].

Proved that the PTEN protein oncosupressor observed in the majority of patients with endometrial adenocarcinoma. It provides control of proliferation, differentiation and apoptotic activity. Recent studies have shown that PTEN is an important factor in the progression of endometrial hyperplasia into cancer. The Kapucuoglu N. et al. research, 2007 in patients with endometrial hyperplasia discovered the relationship between PTEN expression and estrogen receptor, progesterone, and proteins associated with apoptosis [15].

It was shown, that increased phosphoPTEN expression was unchanged in the endometrium and endometrial hyperplasia compared with EA. However, significant differences between simple and complex endometrial hyperplasia were not detected $[15,16]$.

Therefore, the using of phosphoPTEN as a predictive marker of EHP relapse can be considered promising. The impact of phosphoPTEN on the progression of endometrial hyperplasia and malignancy requires further study [16].

Thus, the determination of levels of APRIL, survivin and phosphoPTEN for diagnosis and prediction of recurrence of EHP is actual.

\section{OBJECTIVE}

To evaluate the levels of APRIL, survivin and phosphoPTEN in serum of women with various forms of EHP in combination with uterine fibroids and their prognostic value for recurrence.

\section{MATERIALS AND METHODS}

The study examined 105 women with endometrial hyperplasia and endometrial adenocarcinoma who underwent treatment in the gynecology department "City Clinical Hospital №7»» in Zaporizhzhya and "Zaporozhye Regional Clinical Oncology Center". Patients were divided into groups depending on the particular form of endometrial hyperplasia. The first group consisted of 34 women with simple endometrial hyperplasia without atypia (SEHWA) (mean age 41,6 $\pm 1,31$ years). The second group included 47 patients with complex endometrial hyperplasia without atypia (CEHWA) (mean age 40,9 $\pm 1,34$ years). Groups were divided into subgroups based uterine fibroids. The third group consisted of 26 women with endometrial adenocarcinoma (EA) (mean age 43,59 $\pm 1,43$ years). The control group consisted of 20 women without pathology of the reproductive system. All groups were not significantly differ by age. All patients involved in the study, were investigated by ultrasound on the machine "MyLab50" ( "Esaote", Italy) and videohysteroscopy ( «Karl Storz», Germany). Morphological study conducted in macropreparations postmortem office in "Central Hospital Komunarskyi District." levels of APRIL, survinin and phosphoPTEN in serum were determined by ELISA using reagents Elabscience (USA).

Statistical data processing was performed using the statistical software package "Statistica 6.0 for Windows" (StatSoft Inc., № AXXR712D833214FAN5). Differences between indicators considered reliable on condition $\mathrm{p}<0.05$. The indicators are presented as $\mathrm{M} \pm \mathrm{m}$ (average mean \pm error of the mean) or Me (25-75\%) (median, 25 and 75 percentil) depending on the type of distribution. To assess the reliability of the differences between using double t-criterion of Student for independent samples. For groups of uneven distribution of expected non-parametric Mann-Whitney and Wilcoxon. The study used Pearson and Spearman analysis for calculating the 
correlation. To determine the prognostic significance of ELISA indicators of recurrence of endometrial hyperplasia calculated the odds ratio (OR). The differences are considered significant at $\mathrm{p}<0.05$.

\section{RESEARCH RESULTS}

Analysis the APRIL level expression (Table. 1) showed the increasing of this marker in CEHWA group compared with the control group $(\mathrm{p}<0,05)$ and SEHWA $(\mathrm{p}<0,05)$. Women with EA had significantly higher APRIL levels compared with the control group and patients with both types of endometrial hyperplasia ( $p<0,05)$. Significant differences between the control group and the SEHWA group were not found.

Women with SEHWA had significantly higher levels of survivin compared with the control group ( $p<0,05)$. In patients with adenocarcinoma and CEHWA survivin levels in serum were higher than in the control group and SEHWA $(\mathrm{p}<0,05)$. Significant differences in the level of serum survivin between women with CEHWA and EA were not observed.

Levels of phosphoPTEN in patients with both types of endometrial hyperplasia and adenocarcinoma were higher than in the control group. At the same time, significant differences in levels of phosphoPTEN between these groups were not found.

Table 1

Expression levels of markers APRIL, phosphoPTEN and survivin in patients with endometrial hyperplasia

\begin{tabular}{|l|l|l|l|l|}
\hline Parameters & Control $(\mathrm{n}=20)$ & $\begin{array}{l}\text { SEHWA } \\
34)\end{array}$ & $\begin{array}{l}\text { CEHWA }(\mathrm{n}= \\
47)\end{array}$ & EA $(\mathrm{n}=26)$ \\
\hline APRIL, pg/ml & 37,17 & 32,40 & $60,76^{*}$ & $91,19 \#$ \\
& $(4,60 ; 50,56)$ & $(18,34 ; 50,55)$ & $(26,72 ; 72,39)$ & $(25,76 ; 94,13)$ \\
\hline Survinin, & 35,60 & $60,76 \circ$ & $82,03 *$ & $66,05 \circ$ \\
$\mathrm{pg} / \mathrm{ml}$ & $(20,09 ; 48,71)$ & $(26,72 ; 72,39)$ & $(42,93,126,53)$ & $(21,05 ; 75,56)$ \\
\hline Phospho & 0,092 & $0,238 \circ$ & $0,171 \circ$ & $0,347 \circ$ \\
PTEN, ng / ml & $(0,01 ; 0,17)$ & $(0,02 ; 0,42)$ & $(0,01 ; 0,26)$ & $(0,02 ; 0,35)$ \\
\hline
\end{tabular}

Note: * significant differences with the control group and the group of SEHWA $(p<0,05)$;

\# - significant differences with all groups $(\mathrm{p}<0,05)$;

$\circ$ - significant differences with the control group ( $p<0,05)$.

APRIL level in serum was significantly higher in CEHWA group with uterine fibroids compared with patients without uterine fibroids $(p<0,05)$. In assessing the levels of survivin and phosphoPTEN in women with SEHWA and CEHWA we did not find significant differences depending on the presence of uterine fibroids (Table. 2).

Table 2

Expression the levels of markers APRIL, phosphoPTEN and survivin in women with endometrial hyperplasia combined with uterine fibroids

\begin{tabular}{|c|c|c|c|c|}
\hline Parameter & $\begin{array}{l}\text { SEHWA } \\
\text { without } \\
\text { fibroids }(\mathrm{n}= \\
\text { 18) }\end{array}$ & $\begin{array}{l}\text { SEHWA with } \\
\text { fibroids }(n=16)\end{array}$ & $\begin{array}{l}\text { CEHWA } \\
\text { without fibroids } \\
(\mathrm{n}=20)\end{array}$ & $\begin{array}{l}\text { CEHWA with } \\
\text { fibroids }(n=27)\end{array}$ \\
\hline $\begin{array}{l}\text { APRIL, pg / } \\
\text { ml }\end{array}$ & $\begin{array}{l}39,93 \\
(18,38 ; 68,94)\end{array}$ & $\begin{array}{l}25,54 \\
(18,30 ; 32,17)\end{array}$ & $\begin{array}{l}31,32 \\
(4,60 ; 45,96)\end{array}$ & $\begin{array}{l}78,01 * \\
(18,38 ; 79,07)\end{array}$ \\
\hline $\begin{array}{l}\text { Survinin, pg / } \\
\text { ml }\end{array}$ & $\begin{array}{l}56,78 \\
(7,14 ; 63,62) \\
\end{array}$ & $\begin{array}{l}63,85 \\
(49,97 ; 81,16)\end{array}$ & $\begin{array}{l}85,19 \\
(54,86,123,79)\end{array}$ & $\begin{array}{l}78,06 \\
(25,45,127,73)\end{array}$ \\
\hline $\begin{array}{l}\text { phosphoPTEN, } \\
\text { ng / ml }\end{array}$ & $\begin{array}{l}0,262 \quad(0,13 ; \\
0,42)\end{array}$ & $\begin{array}{l}0,210 \\
0,14)\end{array}$ & $\begin{array}{l}0,182 \\
(0,05 ; 0,11)\end{array}$ & $\begin{array}{l}0,148 \\
(0,01 ; 0,04)\end{array}$ \\
\hline
\end{tabular}

Note: * - significant differences into subgroup CEHWA without uterine fibroids $(\mathrm{p}<0,05)$. 
The study evaluated the prognostic significance of markers APRIL, survivin and phosphoPTEN on recurrence in women with endometrial hyperplasia combined with uterine fibroids. For this purpose, patients were under observation for a year. During this period in 81 women with endometrial hyperplasia, which were monitored, relapse appeared in 21 patients $(25,9 \%)$. The chances of occurrence the new cases of endometrial hyperplasia were increased with raising APRIL more than $43 \mathrm{pg} / \mathrm{ml}(\mathrm{OR}=4,48 ; \mathrm{CI}=1,45-13,83 ; \mathrm{p}<0,05)$ and survivin more than 70 $\mathrm{pg} / \mathrm{ml}(\mathrm{OR}=3,22 ; \mathrm{CI}=1,13-9,16 ; \mathrm{p}<0,05)$. PhosphoPTEN level in serum had no reliable prognostic significance regarding recurrence in patients with endometrial hyperplasia.

In the analysis of the prognostic significance of markers among 43 women with endometrial hyperplasia combined with uterine fibroids involved in the study, recurrence was observed in 14 patients $(32,6 \%)$. In patients with comorbidity reliable prognostic significance has only level of APRIL, which increasing above $43 \mathrm{pg} / \mathrm{ml}$ increased the risk of endometrial hyperplasia during the year $(\mathrm{OR}=4,09 ; \mathrm{CI}=1,22-23,09 ; \mathrm{p}<0,05)$. Markers survivin and phosphoPTEN not significantly increased the risk of recurrence of endometrial hyperplasia.

\section{DISCUSSION OF RESULTS}

Our study found increased the expression of APRIL levels in a row SEHWA, CEHWA and endometrial adenocarcinoma. We anticipate significant differences in CEHWA and EA from the control group. Significant difference between healthy women and SEHWA were not found. Therefore, marker APRIL enables for non-invasive diagnostic of complex endometrial hyperplasia and adenocarcinoma, as well as to differentiate these pathological conditions.

Our study showed that in patients with complex endometrial hyperplasia APRIL expression is higher in the presence of uterine fibroids compare with patients without uterine fibroids. It can be assumed that APRIL plays a role in the development of fibroids in patients with endometrial hyperplasia, as an inducer of proliferation.

Survivin expression increased in women with CEHWA and adenocarcinoma compared with other groups of patients. However, in our study we had not found significant differences between groups CEHWA and adenocarcinoma. Therefore, our data showed, that survivin can be used for the diagnosis these pathological conditions, while at the same time, differentiate between them does not allow it. Also survivin level expression was not significantly different depending on the presence of fibroids in both SEHWA and CEHWA. Therefore, we can assume that this is less informative marker than APRIL for the diagnosis of endometrial hyperplasia combined with uterine fibroids. But it can be useful for diagnostic CEHWA and endometrial adenocarcinoma.

The level of phosphoPTEN expression in all hyperplasia groups and endometrial adenocarcinoma was higher than in the control group. However, significant differences in terms of the marker between these groups were not found. Therefore, phosphoPTEN is uninformative for differential diagnosis of these pathological conditions.

In assessing the prognostic significance of markers in patients with endometrial hyperplasia increased levels of APRIL and survivin were reliable risk factors for recurrence. Women with endometrial hyperplasia and uterine fibroids the only reliable predictor of the onset of relapse was the increasing the expression of APRIL level. Therefore, it can be considered a universal factor for predicting recurrence in patients with endometrial hyperplasia and uterine fibroids.

\section{CONCLUSIONS}

1. APRIL level was highest in patients with endometrial adenocarcinoma and increased significantly from simple to complex endometrial hyperplasia.

2. Survivin level was increased in the women with complex endometrial hyperplasia and adenocarcinoma compared with other women, but significant differences between groups CEHWA and EA were not found.

3. APRIL level in serum was significantly higher in CEHWA group with uterine fibroids compared with patients without fibroids. 
4. Significantly prognostic significance of recurrence regarding of endometrial hyperplasia was raising APRIL level than $43 \mathrm{pg} / \mathrm{ml}(\mathrm{OR}=4,48 ; \mathrm{CI}=1,45-13,83 ; \mathrm{p}<0,05)$ and survivin level than $70 \mathrm{pg} / \mathrm{ml}(\mathrm{OR}=3,22 ; \mathrm{CI}=1,13-9,16 ; \mathrm{p}<0,05)$.

5. In patients with endometrial hyperplasia combined with uterine fibroids significant risk factor for the onset of relapse was an APRIL level increasing above $43 \mathrm{pg} / \mathrm{ml}(\mathrm{OR}=4,09$; $\mathrm{CI}=$ 1,22-23,09; $\mathrm{p}<0,05)$.

6.

\section{LITERATURE}

1. Trimble CL. Management of endometrial precancers. Obstet. Gynecol. 2012; 120 (5): 11601175. DOI: http://10.1097/AOG.0b013e31826bb121.

2. Korniyenko SM. Optymizatsiya likuvannya hiperplastychnykh protsesiv endometriya $\mathrm{v}$ pizn'omu reproduktyvnomMu periodi za dopomohoyu histeroskopichnoyi tekhniky «kholodnoyi petli». Gynecology. 2017; 6 (14): 44-49. DOI: http://dx.doi.org/10.18370/2309-4117.2017.35.4449. Ukrainian.

3. Vovk IB., Gorban NE., Borisyuk OY. Giperplaziya endometriya (Clinical lecture). Woman's health. 2016; 5: 10-18. Ukrainian.

4. Korniyenko SM. Hiperplastychni protsesy endometriya $u$ zhinok $v$ pizn'omu reproduktyvnomu i premenopauzal'nomu periodi: shcho vplyvaye na retsydyvy. Bulletin of the Social Hygiene and Health Organization of Ukraine. 2017; 2: 39-47. Ukrainian.

5. Slyusareva OA. Molekulyarnyye metody diagnostiki giperplazii endometriya. RUDN newspaper. Series: Medicine. 2016; 2: 176-180. Russian.

6. Dronova VL. Kliniko-anamnestychni osoblyvosti ta yakist' zhyttya zhinok z patolohiyeyu endometriya na foni miomy matky. Medical perspectives. 2017; 22 (1): 81-88. Ukrainian.

7. Sparic R., Mirkovic L., Malvasi A., Tinelli A. Epidemiology of Uterine Myomas: A Review. Int. J. Fertil Steril. 2016; 9, N 4: 424-435. DOI: 10.22074 / ijfs.2015.4599.

8. Khan AT., Shehmar M., Gupta JK. Uterine fibroids: current perspectives. Int. J. Womens Health. 2014; 6: 95-114. DOI: 10.2147 / ijwh.s51083.

9. Arjunan Dr. A., Nilavu Dr.J., Thiriveni Balajji Dr. GS. et al. Expression of Bcl-2 and Ki-67 in Cyclical Endometrium and in Endometrial Hyperplasia - An Analysis. Journal of Dental and Medical Sciences. 2016; 15: 43-49. DOI: 10.9790 / 0853-1504084349.

10. Abike F., Tapisiz OL., Zergeroglu S. et al. PCNA and KI-67 in endometrial hyperplasias and evaluation of the potential of malignancy. Eur. J. Gynaecol. Oncol. 2011; 32. No. 1: 77-80.

11. Daud S., Jalil SS, Griffin M. et al. Endometrial hyperplasia - the dilemma of management remains: a retrospective observational study of 280 women. Eur. J. Obstet. Gynecol. Reprod. Biol. 2011; 159: 172-175. DOI: 10.1016 / j.ejogrb.2011.06.023.

12. Ware FC. April and Baff Connect Autoimmunity and Cancer: Figure 1. The Journal Of Experimental Medicine. 2000; 192 (11): F35-F38. DOI: 10.1084 / jem.192.11.f35.

13. Dubrovina SO., Berlim YD. Markery proliferativnoy aktivnosti i angiogeneza u bol'nykh s giperplasticheskimi protsessami endometriya. Reproduction Issues. 2012; (3): 22-27. Russian.

14. Erkanli S., Kayaselcuk F., Kuscu E., Bagis T., Bolat F. et al. Expression of survivin, PTEN and p27 in normal, hyperplastic, and carcinomatous endometrium. Int J Gynecol Cancer 2006; 16: 1412-1418. DOI: 10.1111/j.1525-1438.2006.00541.x

15. Kapucuoglu, N., Aktepe, F., Kaya, H., Bircan, S. et al. Immunohistochemical expression of PTEN in normal, hyperplastic and malignant endometrium and its correlation with hormone receptors, bcl-2, bax, and apoptotic index. Pathology - Research And Practice. 2007; 203 (3): 153-162. DOI: 10.1016 / j.prp.2007.01.003.

16. Lacey JVJr., Mutter GL. PTEN expression in endometrial biopsies as a marker of progression to endometrial carcinoma. Cancer Res. 2008; 68 (14): 6014-20. DOI: 10.1158/00085472.CAN-08-1154.

\section{Conflict of interest is absent}

